\title{
MADRASAH NIZHAMIYAH: SEBUAH MOMENTUM DALAM SEJARAH PENDIDIKAN ISLAM
}

\author{
Novianti Muspiroh \\ IAIN Syekh Nurjati Cirebon (noviantimuspiroh.ak@gmail.com)
}

\begin{abstract}
Madrasah Nizhamiyya is the momentum of the history of Islamic education, the pioneer of institutional Islamic education system, and the driving force behind the establishment of similar institutions in the history of Islamic education. In addition, the birth of this educational institution is also seen as an effort to awaken Sunni orthodoxy. On the other hand, this institution is the starting point for the decline of science, because the supremacy of the religious sciences in it raises the dichotomy and antagonization of various branches of science. Whereas in Islam there is no recognition of the essential separation between the religious sciences and the "profane sciences", because it all boils down to the knowledge of the Only One - the substance of all knowledge.
\end{abstract}

Keywords: Madrasah, education, Sunni

\begin{abstract}
Abstrak
Madrasah Nizhamiyah adalah momentum sejarah pendidikan Islam, pelopor sistem kelembagaan pendidikan Islam, dan pendorong berdirinya lembaga-lembaga serupa dalam sejarah pendidikan Islam. Selain itu kelahiran lembaga pendidikan ini dipandang juga sebagai upaya kebangkitan ortodoksi Sunni. Di lain pihak, institusi ini adalah titik awal bagi kemunduran sains, karena supremasi ilmu-ilmu agama di dalamnya menimbulkan dikotomi dan antagonisasi berbagai cabang ilmu. Sedangkan dalam Islam tidak dikenal pemisahan esensial antara ilmu-ilmu agama dengan "ilmu-ilmu profan", karena semuanya bermuara pada pengetahuan tentang Yang Maha Tunggal - substansi dari segenap ilmu.
\end{abstract}

Kata Kunci: Madrasah, Pendidikan, Sunni

\section{A. Pendahuluan}

Pendidikan Islam mempunyai sejarah yang panjang. Ia tumbuh dan berkembang sejalan dengan hadirnya Islam. Dalam konteks masyarakat Arab, kedatangan Islam dengan segala usahausaha pendidikannya merupakan transformasi besar, sebab masyarakat Arab sebelum Islam tidak mempunyai sistem pendidikan formal dan mereka hidup dalam suatu tatanan yang disebut tatanan Jahiliyah.

Tatanan ini memiliki pola pikir, sikap dan tingkah laku terpuji dan tercela. Termasuk yang terpuji adalah semangat dan keberanian, kedermawanan dan loyalitas kepada suku. Sedangkan termasuk yang tercela adalah politeisme dan paganisme, pemujaan kepada Ka'bah secara berlebihan, perdukunan, khurafat dan mabuk-mabukkan. Dalam hal ini, Islam datang dengan maksud menerima dan mengembangkan yang terpuji dan menolak serta meluruskan yang tercela. ${ }^{1}$ Pada masa yang paling awal, perkembangan pendidikan Islam berlangsung secara informal di rumah-

1 M. Quraish Shihab, Membumikan al-Qur'an. (Bandung, Mizan, 1997), h. 24. 
rumah. Rasulullah telah menjadikan rumah al-Arqam bin Abi al-Arqam ${ }^{2}$ sebagai tempat belajar dan tempat pertemuan dengan para sahabatnya. Di rumah inilah Rasulullah menyampaikan dasar-dasar agama dan mengajarkan alQur'an kepada mereka. ${ }^{3}$ Di samping itu, Rasulullah juga menjadikan rumahnya di Mekkah sebagai tempat berkumpul untuk belajar dan membersihkan akidah mereka, meskipun proses pendidikan seperti ini masih berkaitan dengan upaya-upaya dakwah islamiyah.

Pada perkembangan selanjutnya, setelah masyarakat Islam mulai terbentuk, pendidikan Islam mulai dilembagakan. Hal ini dilakukan untuk peningkatan pelaksanaan pendidikan

\footnotetext{
${ }^{2}$ Abu Abdillah al-Arqam bin Abi al-Arqam (Bahasa Arab الأرقم بن أبي الأرقم) adalah seorang pengusaha yang berpengaruh dari suku Makhzum dari kota Mekkah. Dalam sejarah Islam, dia orang ketujuh dari As-Sabiqun al-Awwalun. Rumahnya berlokasi di bukit Safa, di tempat inilah para pengikut Muhammad belajar tentang Islam. Sebelumnya rumah al-Arqam ini disebut Dar al-Arqam (rumah Al-Arqam) dan setelah dia memeluk Islam akhirnya disebut Dar al-Islam (Rumah Islam). Dari rumah inilah madrasah pertama kali ada. Al-Arqam juga ikut hijrah bersama dengan Muhammad ke Madinah. Dia adalah anggota kabilah Bani Makhzum salah satu kabilah dari suku Quraish. Lihat Muhammad ibn Saad, Tabaqat, vol. 3. Diterjemahkan oleh by Bewley, A. The Companions of Badr, (London: TaHa Publishers, 2013), 185.

3 Ahmad Syalaby. Sejarah Pendidikan Islam, diterjemahakan oleh Mukhtar Yahya dan Sanusi Latief, (Jakarta, Bulan Bintang, 1973), 32; Hasan Langgulung, Asas-asas Pendidikan Islam, (Jakarta: al-Husna, 1988), h.14; M. Athiyah al- Abrasyi, Dasar-dasar Pokok Pendidikan Islam, diterjemahkan oleh Bustami A. Gani dan Djohar Bahry, (Jakarta: Bulan Bintang, 1993), h. 51.
}

Islam. Berkenaan dengan hal ini, para pemerhati sejarah pendidikan Islam telah membagi institusi-institusi pendidikan Islam dalam dua katagori, yaitu periode pra-madrasah dan periode pascamadrasah. ${ }^{4}$ Madrasah dijadikan patokan bagi katagorisasi ini, karena lahirnya madrasah secara historis merupakan bukti awal bagi kemapanan sistem pendidikan Islam, terutama di Timur Tengah. $^{5}$

Disamping itu, sistem madrasah dipandang sebagai jalur pendidikan formal yang di dalamnya terjadi komunikasi secara pedagogis antara pendidik dan anak didik, sehingga terwujud proses belajar mengajar yang dapat mengarah kepada tujuan instruksional $^{6}$ yang memainkan peran mendasar dalam tingkat melek huruf (literacy) yang relatif tinggi di dunia Islam. $^{7}$ Dengan demikian madrasah dianggap sebagai simbol kebangkitan

\footnotetext{
${ }^{4}$ Syalaby, Ahmad, Ibid; Hasan Langgulung, ibid; George Makdisi, The Rise of College: Institutions of Learning in Islam and The West, (Edinburgh: Edinburgh University Press, 1981), 9.

${ }^{5}$ Azyumardi Azra, Jaringan Ulama Timur Tengah dan Kepullauan Nusantara Abad XVII dan XVIII, (Bandung: Mizan, 1998), h. 78.

6 Ramayulis, Ilmu Pendidikan Islam, (Jakarta: Kalam Mulia, 1994), h. 158.

${ }^{7}$ Edmund Burke (June 2009), "Islam at the Center: Technological Complexes and the Roots of Modernity", dalam Journal of World History, (Hawaii: University of Hawaii Press), 20 (2): h. 165-186
} 
sistem pendidikan Islam secara keseluruhan.

Tulisan ini akan mencoba mengkaji kebangkitan madrasah dengan pendekatan sosio-historis, sehingga dapat diketahui faktor-faktor apa yang menjadikan madrasah lahir. Kemudian untuk dapat membuktikan kebangkitan madarasah, maka profil Madrasah Nizhamiyah di Bagdad adalah kajian sentral di dalam tulisan ini.

\section{B. Faktor Penyebab Lahirnya Madrasah}

Untuk mempermudah kajian tentang sejarah pendidikan Islam, para pengkaji bidang ini telah melakukan periodesasi sejarah pendidikan Islam, meskipun periodisasi ini tidak terlepas dari sejarah Islam itu sendiri. Muhammad Munir Mursi membagi perkembangan pendidikan Islam dalam empat periode ${ }^{8}$, yaitu:

1. Periode pembinaan $(610-750 \mathrm{M})$

2. Periode keemasan $(750-1258 \mathrm{M})$

3. Periode kejatuhan dan kemunduran $(1258-1800 \mathrm{M})$

4. Periode pembaharuan dan pembinaan kembali (1800 sekarang)

8 Muhammad Munir Mursi, Al-Tarbiyyah alIslamiyyah: Ushuluha wa Tathawwuruha fi al-Bilad al-Arabiyyah, (Kairo: 'Alam Kutub, 1977), h. 67-68
Setiap periode dari perkembangan pendidikan Islam mempunyai ciri-ciri tersendiri yang menjadi pembeda dengan periode yang lain. Salah satu ciri yang menonjol dari periode keemasan adalah munculnya madrasah-madrasah.

Mengapa madrasah-madrasah muncul pada periode keemasan pendidikan Islam? Faktor apa yang menjadi penyebab kemunculannya? Untuk menjawab pertanyaan ini, tentunya kita harus mengetahui terlebih dahulu situasi dan kondisi institusiinstitusi pendidikan Islam yang ada sebelum madrasah.

Sesungguhnya ada beberapa institusi pendidikan Islam yang telah dijadikan tempat belajar oleh masyarakat muslim sebelum kemunculan madrasah, di antaranya adalah kuttab, masjid dan masjid-khan. ${ }^{9} \quad$ Kuttab adalah tempat belajar yang terletak di rumah guru di mana para murid berkumpul untuk menerima pelajaran. Kuttab dianggap sebagai pendidikan dasar yang ada sebelum Islam, yang digunakan untuk

${ }^{9}$ Ahmad Syalabi, op cit, h. 73; Asma Hasan Fahmi, Sejarah dan Filsafat Pendidikan Islam, diterjemahkan oleh Ibrahim Husein, (Jakarta: Bulan Bintang, 1979), h. 30; M. Athiyah al-Abrasyi, op cit, h. 52; Mehdi Nakosteen, Kontribusi Islam Atas Dunia Intelektual Barat: Deskripsi Analisis Abad Keemasan Islam, diterjemahkan oleh Joko S, Kahar dan Supriyanto, (Surabaya: Risalah Gusti, 1994), h. 2; Munir-Ud-Din Ahmed, Muslim Education and the Scholar's Social Status, (Zurich: Verlag Der Islam, 1968), h. 41; Hasan Langgulung, op cit, h.111; George Makdisi, op cit, h.10. 
belajar tulis baca, kemudian ketika Islam datang digunakan untuk mempelajari alQur'an bagi anak-anak. Selain itu ayatayat al-Qur'an digunakan untuk belajar menulis dengan cara menirunya. Tata bahasa Arab, kisah para nabi dan hadis Rasul juga diajarkan di Kuttab. ${ }^{10}$

Pada masa awal perkembangan Islam, guru-guru kuttab mayoritas adalah non-muslim, karena muslim yang pandai tulis baca, disamping jumlah mereka relatif sedikit juga terlalu sibuk dengan penulisan wahyu. Namun perkembangan kuttab dan guru-gurunya cukup besar, sehingga di setiap desa berdiri sebuah kuttab bahkan terkadang lebih. Ibnu Hauqal menuturkan bahwa ia pernah menghitung 300 orang guru kuttab di sebuah kota, yaitu Palermo, Sicilia. ${ }^{11}$

Charles Michael Stanton membagi kuttab kepada dua jenis, yaitu untuk pendidikan sekular dan satu lagi untuk pendidikan agama. Para guru kuttab sekular yang mengajarkan sastra, berhitung dan lain-lain selalu mendapatkan imbalan jasa, walaupun sangat sederhana. Sedangkan para ulama

10 Philip K. Hitti, 1974. History of the Arab. (London: McMillan Press Ltd), h. 408; Ahmad Amin, Dluha al-Islam, Jilid II, (Kairo: Lajnah Ta'lif wa al-Tarjamah wa al-Nasyr, 1952), h. 50; Clifford Edmund Bosworth, M. S. Asimov, The Age of Achievement: A.D. 750 to the End of the Fifteenth Century : The Achievements (History of Civilizations of Central Asia),(Unesco, 2000), h. 33-4.

${ }^{11}$ Ahmad Syalaby, op cit, h. 44. yang mengajarkan agama tidak menerima imbalan untuk jasa ini. Bangunan kuttab kadang-kadang berada pada satu kamar khusus di rumah ulama atau sebuah ruangan di samping yang hanya dapat menampung beberapa anak saja dan ada pula yang besar dan luas. ${ }^{12}$ Dengan demikian, kuttab masih bersifat sederhana dan tidak memiliki fasilitas belajar yang lengkap.

Selain istilah kuttab ada lagi istilah maktab. Pemakaian istilah ini di kalangan masyarakat Islam tidaklah secara simultan. Menurut Muniruddin Ahmad, pada awal perkembangan Islam istilah yang lebih populer dipakai adalah kuttab. $^{13}$ Sedangkan A.L. Tibawi berpendapat sebaliknya. Menurutnya, terma maktab lebih banyak digunakan dalam periode klasik sedangkan terma kuttab lebih banyak digunakan pada masa modern. Namun, sepanjang sejarah Islam kedua terma itu digunakan secara bergantian. ${ }^{14}$ Yang jelas dari perbedaan istilah ini tidaklah merupakan suatu yang prinsip karena keduanya memiliki persamaan maksud dan tujuan.

\footnotetext{
12 Fakhrur Razy Dalimunthe, Sejarah pendidikan Islam: Latar Belakang, Analisis dan Pemikirannya, (Medan: Rimbow, 1986), h. 87.

${ }^{13}$ Muniruddin Ahmad, Muslim Education and the Scholars Social Status up to the 5th Century Muslim Era, (Zurich: Verlag der Islam, 1968), h. 41-42.

14 A.L. Tibawi, Islamic Education: Its Traditions and Modernization into the Arab National System, (London, Luzac and Company Ltd, 1972), h. 26.
} 
Adapun masjid muncul sebagai pusat pendidikan lanjutan dan pendidikan tinggi bagi remaja dan orang dewasa dalam ilmu-ilmu agama. Sebenarnya masjid pada pertama kalinya merupakan tempat untuk pendidikan dasar. Akan tetapi, orangorang Islam berpendapat adalah lebih baik memisahkan pendidikan anak-anak pada tempat tertentu, demi menjaga kehormatan masjid dari keributan anakanak dan karena mereka belum mampu menjaga kebersihan masjid. Adalah yang menjadikan masjid sebagai pusat ilmu pengetahuan dan kebudayaan karena pelajaran pada tahun-tahun pertama lahirnya Islam adalah berupa pelajaran agama tentang dasar-dasar Islam. Pelajaran semacam ini erat kaitannya dengan masjid. Sistem belajar yang dilaksanakan di masjid adalah sistem halaqah (study-circles). Halaqah membentuk lingkaran mengelilingi seorang syaikh yang dengan kefasihan bicara dan kedalaman pengetahuannya dapat menarik pendengar. Menurut Charles Michael Stanton, pada awalnya seorang menjadi syaikh secara alami dan statusnya ditentukan oleh pengikutnya. Kemudian dengan persiapan formal, seorang syaikh halaqah dapat diangkat menjadi pengurus masjid. ${ }^{15}$ Besar dan

15 Charles Michael Stanton, Pendidikan Tinggi kecilnya suatu halaqah tergantung kepada kecakapan dan kemasyhuran seorang syaikh. Di dalam sebuah masjid terkadang ada beberapa halaqah dan beberapa orang syaikh. Pada perkembangan selanjutnya, para syaikh secara khusus diangkat menjadi guru agama dan memimpin halaqah, sehingga sejarah lembaga formal pendidikan tinggi berawal dari terbentuknya halaqah-halaqah masjid.

Sedangkan masjid-khan merupakan perkembangan lebih lanjut dari masjid yang dilengkapi dengan sarana akomodasi bagi pihak belajar. Istilah khan dapat diterjemahkan sebagai pemondokan (penginapan musafir), tetapi dalam hubungan ini, istilah tersebut berarti asrama mahasiswa yang berasal dari desa-desa yang jauh, yang pada umunya belajar fiqih. Menurut George Makdisi, masjid-khan (the masjid-khan complex) berkembang sekitar awal abad ke-4 H/10 M. Lembaga ini didukung sepenuhnya dari dana wakaf. ${ }^{16}$ Masjid-khan mengambil satu langkah lebih maju dengan menyediakan akomodasi atau mungkin juga makanan bagi para pelajar. Akan

dalam Islam, diterjemahkan oleh Affandi dan Hasan Asarij, Judul asli:Higher Learning in Islam: the Classical Period, A.D. 700-1.300, (Jakarta: Logos, 1994), h. 24.

${ }^{16}$ George Makdisi, op cit, h. 28. 
tetapi, dikarenakan masjid-khan tetap termasuk dalam katagori masjid, maka penggantian pemimpinnya berada dalam batas hak prerogatif khalifah atau wakilnya.

Institusi-institusi pendidikan Islam di atas senantiasa mengalami perkembangan seiring dengan kemajuan peradaban Islam. Perhatian yang besar dari para pembesar atau dermawan terhadap bidang pendidikan mendorong terciptanya jaringan ilmiah. Oleh karena berbagai tuntutan yang ada, muncul kebutuhan akan suatu lembaga pendidikan yang secara khusus digunakan untuk pendidikan. Maka lahirlah madrasah yang dianggap dapat menjawab tuntutan tersebut.

Dalam hal ini, Mahmud Yunus menyebutkan empat faktor yang menjadi sebab munculnya madrasah, ${ }^{17}$ yaitu:

1. Untuk mengambil hati rakyat. Ini adalah faktor politik yang berkaitan dengan pendidikan. Para penguasa berusaha untuk dapat mengambil hati rakyat dengan jalan memajukan agama dan mementingkan pendidikan.

Mereka berani mengeluarkan dana yang besar untuk membangun sebuah madrasah.

17 Mahmud Yunus, Sejarah Pendidikan Islam, (Jakarta: Hidakarya Agung, 1990), h. 71.
2. Untuk mengharapkan pahala dan ampunan dari Allah. Faktor religius ini menjadi motivasi bagi lahirnya madrasah. Para penguasa yang hidup mewah dengan pemuasan hawa nafsu bermaksud beramal menyiarkan agama dengan mendirikan madrasahmadrasah, dengan harapan agar mereka mendapat ampunan dan keridhoan Allah.

3. Untuk memelihara kehidupan anaknya kemudian hari. Faktor ekonomi juga mempunyai pengaruh bagi lahirnya madrasah. Para penguasa dan orang-orang kaya mewakafkan hartanya untuk pembangunan madrasah dengan syarat yang menjadi pengurusnya adalah anak-anak mereka, secara turun-temurun.

4. Untuk memperkuat aliran keagamaan bagi sultan atau pembesar. Ini adalah faktor fanatisme yang membuat para pembesar mendirikan madrasah dengan maksud memperkuat madzhabnya.

Keempat faktor di atas sesungguhnya berkaitan dengan kepentingan para pendiri madrasah, baik dari kalangan para penguasa maupun para dermawan. Faktor-faktor ini belum 
dapat mewakili mengapa madrasah lahir secara keseluruhan.

Menarik memperhatikan pendapat Mehdi Nakosteen yang mengatakan bahwa madrasah lahir karena dua faktor, yaitu intern dan ekstern. Secara Internal, pendidikan yang diberikan di kuttab, masjid dan masjid-khan memiliki beberapa keterbatasan. Kurikulumnya serba terbatas dan fasilitas fisiknya tidak mendukung bagi lingkungan pendidikan yang memadai. Pertentangan antara tujuan pendidikan dan tujuan agama hampir tidak dapat ditemukan komprominya. Tujuan pendidikan menghendaki adanya aktivitas pendidikan sehingga tidak jarang menimbulkan suasana hiruk pikuk, sementara beribadah di masjid menghendaki ketenangan dan kekhusyuan. Oleh karena itu, dididirikannya lembaga pendidikan dengan bentuk baru, yaitu madrasah adalah sesuatu yang wajar dan diperlukan. Sedangkan secara eksternal, adalah kenyataan bahwa kemajuan dan penyebaran ilmu pengetahuan menyebabkan adanya sekelompok orang yang menemui hambatan untuk mencapai kehidupan yang layak melalui pengembangan ilmu pengetahuan. Dengan demikian dalam rangka memajukan pendidikan, diperlukan sistem penggajian kepada mereka sebagaimana telah diwujudkan oleh madrasah-madrasah.

Jika kita membandingkan dengan pendapat Mahmud Yunus di atas dengan pendapat Mehdi Nakosteen, maka dapatlah dikatakan bahwa pendapat Mahmud Yunus masuk pada katagori faktor eksternal sebagaimana dikemukakan Mehdi Nakosteen.

Dari keterangan di atas, jelaslah bahwa munculnya madrasah dapat dianggap sebagai suatu jawaban lanjutan bagi mesin pendidikan Islam yang semakin maju. Madrasah tidak menggantikan fungsi masjid, karena kenyataannya banyak madrasah mempunyai masjid di dalamnya. Fungsi utama madrasah bukan untuk tempat ibadah, Ia merupakan jawaban terhadap tantangan dan kebutuhan akan suatu lembaga pendidikan yang lebih profesional.

\section{Madrasah Nizhamiyah: Sebuah Pengalaman}

Para pakar sejarah pendidikan Islam kiranya masih berbeda pendapat seputar pertanyaan madrasah manakah yang muncul lebih awal dalam kelembagaan pendidikan Islam? Ada dua jawaban terhadap pertanyaan ini. Kelompok pertama menyebutkan bahwa 
madrasah sudah ada jauh sebelum Madrasah Nizhamiyah, dan menurut mereka yang pertama kali muncul adalah al-Madrasah al-Baihaqiyah di Nishapur, Iran, sekitar seperempat pertama abad ke-11 M (akhir abad ke-4 H). ${ }^{18}$ Sementara menurut Naji Ma'luf bahwa eksistensi madrasah di Ma Waraa alNahr dan Khurasan sekitar 105 tahun sebelum Madrasah Nizhamiyah, merupakan pionir pertama madrasah. ${ }^{19}$ Kelompok kedua menyatakan kemunculan madrasah diawali oleh Madrasah Nizhamiyah di Bagdad yang berdiri pada tahun $1067 \mathrm{M} / 459 \mathrm{H}^{20}$

Sebenarnya kedua kelompok yang berbeda pendapat di atas dapat dikompromikan. Memang betul bahwa sistem madrasah pertama kali muncul di Nishapur, tetapi tersiarnya madrasah dengan luas adalah semenjak dididirikannya Madrasah Nizhamiyah. Disamping itu, dari sudut organisasi dan lembaga, Madrasah Nizhamiyah adalah madrasah pertama yang berbentuk

${ }^{18}$ Richard W. Bulliet, The Patricians of Nishapur: A Study in Medievel Islamic Social History, (Cambridge: Harvard University Press, 1972), h. 249-255; Azyumardi Azra, op cit, h. 62; Asma Hasan Fahmi, op cit, h. 41; M. Athiyah al-Abrasyi, op cit, h. 79.

19 Naji Ma'luf, Madaris Qabla al-Nizamiyah, (Bagdad: Majma' al-Ilmi al-Iraci, 1973), h. 8.

${ }^{20}$ Mehdi Nakosteen, op cit, h. 52; Ahmad Syalabi, op cit, h. 112; Charles Michael Stanton, op cit, h. 45; Muhammad Munir Mursi, Al-Tarbiyyah alIslamiyyah: Ushuluha wa Tathawwuruha fi al-Bilad al-Arabiyyah, (Kairo, 'Alam Kutub, 1977), h. 88. lembaga yang secara sistematis dan dapat membawa sebuah lembaga ke puncak perkembangan pendidikan Islam. $^{21}$

\section{Menurut George Makdisi,} madrasah merupakan fase ketiga dari garis perkembangan institusi pendidikan Islam dengan urutan: masjid, masjidkhan dan madrasah. ${ }^{22}$ Oleh karena itu, Madrasah Nizhamiyah juga lahir dari sebuah perkembangan yang evolutif, yang senantiasa memerlukan waktu untuk berproses secara historis.

Madrasah Nizhamiyah didirikan pada masa pemerintahan Dinasti Bani Saljuq $^{23}$ oleh perdana menteri (wazir)

${ }^{21}$ Fazlurrahman, Islam, diterjemahkan oleh Ahsin Mohammad, (Bandung: Pustaka, 1997), h. 268.

${ }^{22}$ George Makdisi, op cit, h. 27.

23 Bani Saljuk atau Turki Seljuk adalah sebuah dinasti Islam yang pernah menguasai Asia Tengah dan Timur Tengah dari abad ke 11 hingga abad ke 14. Mereka mendirikan kekaisaran Islam yang dikenali sebagai Kekaisaran Saljuk Agung. Kekaisaran ini terbentang dari Anatolia hingga ke Rantau Punjab di Asia Selatan. Kekaisaran ini juga adalah sasaran utama Tentara Salib Pertama. Dinasti ini didirikan oleh suku Oghuz Turki yang berasal dari Asia Tengah. Dinasti Saljuk juga menandakan penguasaan Bangsa Turki di Timur Tengah. Pada hari ini, mereka dianggap sebagai pengasas kebudayaan Turki Barat yang ketara di Azerbaijan, Turki dan Turkmenistan dan Seljuk juga dianggap sebagai penaung Kebudayaan Persia. Dinasti Saljuk berasal dari daerah pegunungan dan stepa Turkistan. Menjelang akhir abad ke-2 $\mathrm{H}$ atau abad ke-8 $\mathrm{M}$. orang-orang Oghuz pindah ke arah barat melalui dataran tinggi Siberia ke Laut Arab dan sebagian ke wilayah Rusia. Lihat Michael S. Neiberg, Warfare in World History. (Abingdon, United Kingdom: Routledge, 2002), h. 19-20; Jonathan Harris, Byzantium and the Crusades, (London, United Kingdom: Bloomsbury Publishing, 2014), h. 39-45; Greville Stewart Parker Freeman-Grenville, Stuart Christopher Munro-Hay, Islam: An Illustrated 
Nizham al-Mulk $(1018$ - $1092 \mathrm{M}) .{ }^{24}$ Dia adalah seorang ilmuwan yang telah mengarang buku yang berjudul "Siyasat Nama" yang salah satu tema sentralnya adalah persatuan Islam melalui doktrin ortodoks yang dicanangkan oleh madrasah-madrasah. ${ }^{25}$

Madrasah-madrasah yang didirikan Nizham al-Mulk disebut Madrasah Nizhamiyah. Madrasah-madrasah ini termasyhur di seluruh wilayah Islam. Pada setiap kota, Nizham al-Mulk mendirikan sebuah madrasah, diantaranya di Bagdad, Balk, Naisabur, Herat (Iran), Basrah, Isfahan, Merv, Mosul (Irak) dan lain-lain. Dari sekian banyak madrasah, Madrasah Nizhamiyah di Bagdad adalah yang terbesar dan paling terkenal.

\section{Madrasah Nizhamiyah Bagdad} dibangun untuk pertama kalinya pada tahun $457 \mathrm{H} / 1065 \mathrm{M}$ dan selesai pembangunannya tahun $459 \mathrm{H} / 1067 \mathrm{M}$. Madrasah ini terletak di pinggir sungai

History, (London, United Kingdom: Bloomsbury Academic, 2006), h. 51.

${ }^{24}$ Montgomery Watt, Kejayaan Islam: Kajian Kritis dari Tokoh Orientalis, diterjemahkan oleh Hartono Hadikusumo, (Yogyakarta: Tiara Wacana, 1990), h. 247-249; Badri Yatim, Sejarah Peradaban Islam, (Jakarta: Rajawali Pers, 1994), 72; A. Hasjmy, Sejarah Kebudayaan Islam, (Jakarta: Bulan Bintang, 1995), h. 213.

${ }^{25}$ J. Pederson, Fajar Intelektualisme Islam: Buku dan Sejarah Penyebaran Informasi di Dunia Arab, diterjemahkan oleh Alwiyah Abdurrahman, (Bandung: Mizan, 1996), h. 166.
Dajlah (Tigris), di tengah-tengah pasar Selasah di Bagdad. ${ }^{26}$

Tujuan utama dibangunnya Madrasah Nizhamiyah Bagdad adalah mengajar hukum madzhab Syafi'i (Sunni) dengan penekanan pada pengajaran teologi dan hukum Islam (fiqh). Dengan berlandaskan tujuan ini, ada beberapa motif dibangunnya Madrasah Nizhamiyah Bagdad. Hasan Asari menyebutkan bahwa empat motif tersebut, ${ }^{27}$ adalah:

\section{Pendidikan}

Nizham al-Mulk adalah seorang sarjana dan ahli hadis, sehingga perhatiannya terhadap pendidikan dengan mendirikan madrasah, adalah suatu yang wajar dan pantas.

2. Konflik antar kelompok keagamaan

Perdana Menteri sebelum Nizham al-Mulk adalah al-Kunduri yang bermadzhab Hanafi dan pendukung Mu'tazilah. Salah satu kebijaksanaannya adalah mengusir dan menganiaya para peganut Asy’ariyah. Oleh karena itu, pada

\footnotetext{
${ }^{26}$ Muhammad al-Qurtary, al-Jami'ah al-Islamiyyah wa Dauruha fi Masirat al-Fikr al-Tarbawy, (Kairo: Daar al-Kutub al-'Araby, t.t.), h. 62.

27 Hassan Asari, Menyingkap Zaman Keemasan Islam, (Bandung: Mizan, 1994), h. 51-52.
} 
saat Nizham al-Mulk menjabat sebagai wazir, ia berhadapan dengan kelompok Mu'tazilah. Pendirian madrasah merupakan usaha Nizham al-Mulk untuk membela Syafi'iyah dan Asy’ariyah.

3. Pendidikan bagi pegawai pemerintah

Sebagai seorang wazir, Nizham alMulk memperhatikan satu sistem administrasi negara yang terdiri dari para penduduk yang bervariasi latar belakang kehidupannya. Dalam hal ini, madrasah membantu mengeluarkan para lulusan yang siap bekerja untuk pemerintahannya.

\section{Politik}

Madrasah Nizhamiyah berfungsi sebagai alat politik bagi Nizham al-Mulk dalam rangka membangun hubungan dengan penguasa dan masyarakat agar posisinya di pemerintahan tetap stabil.

Setelah gedung madrasah selesai dibangun, Nizham al-Mulk menetapkan para pengajar untuk mengajar di madrasahnya. Di antara para pengajar itu adalah: Abu Ishaq al-Syirazi (w. 476 H/1083 M), Abu Nashr al-Shabbagh (w. 477 h/1084 M), Abu al-Qasim al-'Alawy (w. 482 H/1089 M), Abu Abdillah alThabari (w. 495 H/1101 M), Abu hamid al-Ghazali (w. 505 H/1111 M), alQazwaini (w. 575 H/1179 M) dan alFairuzabadi (w. 817 H/1414 M). Melihat para pengajar yang ada, Madrasah Nizhamiyah dapat dikatakan sebagai madrasah fiqh (syari'ah), bukan madrasah filsafat. Hal itu karena zaman berdirinya Madrasah Nizhamiyah adalah zaman tertindasnya kajian filsafat dan para filosof.

Madrasah Nizhamiyah Bagdad, seperti halnya madrasah lain yang dibangun Nizham al-Mulk, tetap berada di bawah kontrol Nizham al-Mulk selama hidupnya. Oleh karena itu sistem pendanaannya berasal dari wakaf pemerintah. Hal ini terbukti dari Dokumen Wakaf Madrasah Nizhamiyah, sebagaimana diungkapkan A.S. Tritton ${ }^{28}$ sebagai berikut:

1. Madrasah Nizhamiyah merupakan wakaf yang disediakan untuk kepentingan madzhab Syafi'i dalam fiqh dan ushul fiqh.

2. Harta benda yang diwakafkan kepada Madrasah Nizhamiyah adalah untuk kepentingan

\footnotetext{
${ }^{28}$ A.S. Tritton, Materials on Muslim education in the Middle Ages, (London: Luzac and Company, 1957), h. 103-104.
} 
penganut madzhab Syafi'i dalam fiqh dan ushul fiqh.

3. Pejabat-pejabat utama Madrasah Nizhamiyah harus bermadzhab Syafi'i dalam fiqh dan ushul fiqh.

4. Madrasah Nizhamiyah harus mempunyai seorang tenaga pengajar bidang kajian alQur'an

5. Madrasah Nizhamiyah harus mempunyai tenaga pengajar bahasa Arab.

6. Setiap staf menerima bagian tertentu dari penghasilan yang diperoleh dari harta wakaf Madrasah Nizhamiyah.

Melihat Dokumen di atas, Azyumardi Azra berpendapat bahwa Madrasah Nizhamiyah merupakan prototipe kebangkitan ortodoksi Sunni. Hal senada juga diungkapkan Mehdi Nakosteen bahwa madrasah-madrasah Nizhamiyah, selain memiliki spirit ilmu pengetahuan yang tinggi, baik propaganda dan aksi politik maupun agama, juga membentuk opini publik Islam Sunni ortodoks mengikis faham Syi'ah dan Ismailiyah.

Bisa disimpulkan bahwa para sejarawan sepakat bahwa Madrasah Nizhamiyah adalah madrasah Sunni, namun ada sesuatu yang khusus bahwa
Sunni yang dimaksud adalah madzhab Syafi'iyah dengan kalam Asy'ariyah, sesuai degan kecenderungan pribadi Nizham al-Mulk sendiri. Sedangkan raja-raja Dinasti Saljuk adalah pemeluk fanatik Sunni dengan madzhab Hanafi dan kalam Maturidiyah. Kondisi seperti ini, ternyata tidak menjadi masalah bagi raja-raja Saljuk. Yang penting bagi mereka adalah kelanggengan kekuasaannya. Oleh karena itu sikap membiarkan Nizham al-Mulk dan penganut madzhabnya dapat dimanfaatkan untuk melawan Syi'ah yang waktu itu merupaklan musuh utamanya. Sebelumnya, penguasa Saljuk yang pertama, Tugril Bek membiarkan menterinya Amid al-Malik al-Kunduri bersikaf dekat dengan golongan Mu'tazilah disebabkan keuntungan strategis untuk melawan pengikut Syafi'iyah Asy'ariyah yang merupakan oposisi mereka. $^{29}$

Lebih jauh pendapat ini dikuatkan dengan anggapan bahwa Nizham alMulk sendiri mengatur kurikulum dan pengawasan stafnya, sehingga memungkinkan bagi dirinya melakukan pergantian pemimpin lepas dari kontrol khalifah. Sebuah tindakan politik yang mempunyai akibat besar pada madrasah.

\footnotetext{
29 Maksum, Madrasah: Sejarah dan Perkembangannya, (Jakarta: Logos, 1999), h. 62.
} 
Dengan memisahkan asrama siswa dari masjid, ia membebaskan lembaga ini dari kontrol keagamaan secara langsung dari pemerintah, tetapi pada waktu yang bersamaan tetap berada dalam arus utama masyarakat yang berorientasi keagamaan. Madrasah melambangkan keunikan dari sebuah lembaga pendidikan tinggi yang bersifat pribadi atau swasta.

Di antara materi dari kurikulum yang diajarkan adalah pengajaran kalam. Materi ini memang diberikan di Madrasah Nizhamiyah, namun cakupannya terbatas yang dibutuhkan bagi pengajaran fiqih. Nampaknya peluang materi ini memang ada. Motif politik yang melatarbelakangi lahirnya madrasah memberikan konsekuensi logis pada urgensi pengajaran kalam. Madrasah Nizhamiyah adalah lembaga pendidikan yang bertujuan sebagai propaganda Asy'ariyah untuk memenangkan kalam mereka atas Mu'tazilah dan kelompok Hambali. ${ }^{30}$ Namun tendensi ini bukan berarti madrasah adalah lembaga pendidikan teologi. Al-Ghazali sebagai salah seorang staf pengajar Madrasah Nizhamiyah adalah seorang filosof. Anggapan ini tentunya dapat kita fahami

${ }^{30}$ Ignaz Goldziher, Introduction to Islamic Theology and Law, (Princenton: Princenton University Press, 1981), h. 71. dari tindakannya yang menentang dan menyanggah argumentasi para filosof lain tentang pemikiran filosofis keagamaan yang dianggap telah menyimpang. Sanggahan ini tentunya tidak bisa terlepas dari pemikiran filosofis al-Ghazali sendiri. Disamping itu ia dalam menunaikan tugasnya sebagai guru besar di Madrasah Nizhamiyah mengajarkan ilmu-ilmu agama. Ilmu-ilmu agama ini tidak hanya terbatas pada fiqih saja, tetapi termasuk pula ilmu kalam.

Maksum mensinyalir adanya rasionalitas dari kandungan madrasah walaupun terfokus pada fiqih yang bersifat sangat terbatas. Jadi ilmu-ilmu agama tetap menjadi primadona kandungan madrasah, sebaliknya "ilmuilmu profan" berada pada posisi marjinal. Pendapat ini tidak terlepas dari konsensus bahwa Madrasah Nizhamiyah adalah perwujudan dari lembaga pendidikan fiqih atau college of law. ${ }^{31}$

Fenomena di atas merupakan salah satu kelemahan madrasah, sehingga tidak bisa diandalkan bagi pengembangan ilmu pengetahuan. Ajaran rasionalitas baru memiliki peluang masuk ke dalamnya seiring timbulnya madzhab fiqih yang empat dan keterkaitan terhadap produk-produk

${ }^{31}$ Maksum, op cit, h. 71. 
dan metode-metode madzhabnya. Jalan rasionalitas yang ditempuh adalah ta'wil dan qiyas. Celah rasionalitas di dalam madrasah hanya dibatasi oleh karakter ilmu fiqih yang takut terhadap pengaruh lupa dan pencampuran lafadz yang menurut para fuqaha akan berpengaruh besar terhadap hukum. Ilmu-ilmu ini tidak dilangsungkan secara kreatif imajinatif. Ijtihad bersifat terbatas, karena dicekik secara sempurna oleh penutupan pintu ijtihad itu sendiri. Akibatnya ilmu fiqih yang ditransmisikan melalui madrasah itu tidak lebih daripada upaya "pengawetan" doktrin-doktrin yang sebagiannya telah usang dan tidak bisa menjawab realitas sosial yang senantiasa berubah. ${ }^{32}$

Alhasil, akibat pengkonsentrasian kandungan madrasah pada ilmu-ilmu syariah bermuara pada merosotnya perkembangan ilmu-ilmu rasional. Padahal inilah yang menjadikan Islam mundur di bidang sains. Dengan demikian madrasah ikut andil juga dalam kemunduran ini. Sejarah mencatat Islam mencapai masa keemasan justru karena akrab dengan ilmu-ilmu ini. Pada masa itu muncul ilmuwan-ilmuwan dengan

${ }^{32}$ Azyumardi Azra, "Pendidikan Tinggi Islam dan Kemajuan Sains: Sebuah Pengantar" dalam Pendidikan Tinggi dalam Islam, Charles Michael Stanton, diterjemahkan oleh Afandi dan Hasasn Asari, (Jakarta, Logos, 1994), h. x. teori-teori yang ditemukan diberbagai bidang ilmu, seperti kedokteran, astranomi dan lain-lain. Jika madrasah muncul pada masa keemasan Islam era Abbasiyah, tentunya ilmu-ilmu rasional merupakan bagian kurikulumnya. Oleh karena itu munculnya madrasah berada pada tingkat yang sudah terlambat dalam perkembangan kebudayaan Islam.

Supremasi ilmu-ilmu agama menimbulkan dikotomi dan antagonisasi berbagai cabang ilmu. Sedangkan dalam Islam tidak dikenal pemisahan esensial antara ilmu-ilmu agama dengan "ilmuilmu profan', karena semuanya bermuara pada pengetahuan tentang Yang Maha Tunggal - substansi dari segenap ilmu.

Adapun pola interaksi antara siswa dan guru di madrasah terjalin secara akrab. Siswa menganggap gurunya sebagai seorang ayah dan mematuhinya, meskipun dalam masalah pribadi, yang tidak bersangkutan dengan studi formalnya. Suasana di madrasah santai dan non-formal sekali, tanpa ada tekanan berat akademis suatu finansial bagi para siswa. Seseorang mungkin tetap menjadi siswa sepanjang hidupnya, menguasai subyek demi subyek yang lainnya dan berpindah dari seorang guru ke guru berikutnya. Biasanya seelah ia menguasai satu subyek yang membuat gurunya merasa cukup dan puas. Ia 
memperoleh izin (ijazah) dari guru yang menyatakan kemampuannya dalam subyek tersebut. Jika siswa itu pintar, besar kemungkinan ia mendapat giliran menjadi guru dan memberi siswanya pula ijazah. Walaupun dalam cara belajar yang paling formal sekalipun, kuliah mendengarkan mahaguru dan menerima ijazah secara pribadi, terus menghidupkan satu rantai (isnad) penyalur, yang sangat penting dalam menjaga dan mengabdikan tradisi pendidikan Islam. Dalam proses ini, kontak yang akrab antara guru dan siswa serta lamanya waktu hidup bersama, seringkali dalam perumahan yang sama, banyak membantu memungkinkan penyampaian warisan semangat maupun misi berbagai cabang pengetahuan, yang sering kali berguna bagi fungsi masyarakat Islam secara formal. ${ }^{33}$

\section{Penutup}

Kemunculan madrasah dalam dunia kelembagaan pendidikan Islam merupakan upaya evolusi historis dalam rangka mewujudkan institusi pendidikan Islam yang lebih profesioonal. Madrasah dapat dipandang sebagai bukti awal bagi kemapanan sistem pendidikan Islam.

\footnotetext{
${ }^{33}$ Seyyed Hossein Nasr, Science and Sivilization in Islam, (Cambridge, Massachusetts: Harvard University Press, 1968), h. 72.
}

Secara organisatoris-administratif, Madrasah Nizhamiyah Bagdad merupakan madrasah pertama yang muncul dalam sistem kelembagaan pendidikan Islam. Ia didirikan oleh Nizham al-Mulk, seorang perdana menteri Dinasti Bani Saljuq yang hidup pada masa kekuasaan Alp-Arsalan dan Malik Shah. Madrasah ini lahir karena adanya faktor internal dan eksternal.

Munculnya Madrasah Nizhamiyah di bawah kekuasaan Bani Saljuq dipandang sebagai upaya kebangkitan kembali ortodoksi Sunni. Nizham alMulk memberikan perhatian dan dukungan yang begitu besar terhadap madrasahnya, agar dapat menegakkan kembali fiqh Syafi'i dan teologi Asy'ariyah.

\section{Daftar Pustaka}

Abrasyi, M. Athiyah al-, 1993, Dasardasar Pokok Pendidikan Islam, diterjemahkan oleh Bustami A. Gani dan Djohar Bahry, Jakarta: Bulan Bintang.

Ahmad, Muniruddin, 1968, Muslim Education and the Scholars Social Status up to the $5^{\text {th }}$ Century Muslim Era, Zurich: Verlag der Islam, Ahmed, Munir-Ud-Din, Muslim Education and the Scholar's Social Status, Zurich: Verlag Der Islam.

Amin, Ahmad, 1952, Dluha al-Islam, Jilid II, Kairo, Lajnah Ta'lif wa alTarjamah wa al-Nasyr, 
Asari, Hassan, 1994, Menyingkap Zaman Keemasan Islam, Bandung: Mizan.

Triton, A.S., 1957, Materials on Muslim Education in the middle Ages, London: Luzac \& Company.

Azra, Azyumardi, 1994, "Pendidikan Tinggi Islam dan Kemajuan Sains: Sebuah Pengantar" dalam Pendidikan Tinggi dalam Islam, Charles Michael Stanton, diterjemahkan oleh Afandi dan Hasasn Asari, Jakarta: Logos. , 1998, Jaringan Ulama Timur Tengah dan Kepullauan Nusantara Abad XVII dan XVIII, Bandung: Mizan.

, 1998, "Rekontruksi Kritis Ilmu dan Pendidikan Islam," dalam M. Anies dkk. (eds), Religiusitas IPTEK, Yogyakarta, Pustaka Pelajar.

Bosworth, Clifford Edmund, dan M. S. Asimov, 2000, The Age of Achievement: A.D. 750 to the End of the Fifteenth Century: The Achievements (History of Civilizations of Central Asia), Unesco.

Bulliet, Richard W. 1972, The Patricians of Nishapur: A Study in Medievel Islamic Social History, Cambridge: Harvard University Press.

Burke, Edmund, June 2009, "Islam at the Center: Technological Complexes and the Roots of Modernity", dalam Journal of World History, Hawaii: University of Hawaii Press), 20 (2): h. 165-186.

Charles Michael Stanton, 1994, Pendidikan Tinggi dalam Islam, diterjemahkan oleh $\mathrm{H}$. Afandi dan hasan Asari, Jakarta: Logos.

Dalimunthe, Fakhrur Razy, 1986, Sejarah pendidikan Islam: Latar
Belakang, Analisis dan Pemikirannya, Medan: Rimbow.

Fahmi, Asma Hasan, 1979, Sejarah dan Filsafat Pendidikan Islam, diterjemahkan oleh Ibrahim Husein, Jakarta: Bulan Bintang.

Fazlurrahman, 1997, Islam, diterjemahkan oleh Ahsin Mohammad, Bandung: Pustaka.

Goldziher, Ignaz, 1981, Introduction to Islamic Theology and Law, Princenton: Princenton University Press.

Grenville, Greville Stewart Parker Freeman-, 2006, Stuart Christopher Munro-Hay, Islam: An Illustrated History, London, United Kingdom: Bloomsbury Academic.

Harris, Jonathan, 2014, Byzantium and the Crusades, London, United Kingdom: Bloomsbury Publishing.

Hasjmy, A. 1995, Sejarah Kebudayaan Islam, Jakarta: Bulan Bintang,

Hitti, Philip K. 1974, History of the Arabs, London: Mac Millan Press.

Langgulung, Hasan, 1988, Pendidikan Islam Menghadapi Abad ke-21, Jakarta: al-Husna.

, 1988, Asas-asas Pendidikan Islam, Jakarta: alHusna.

Lapidus, Ira M., 1972, a History of Islamic Societies, Cambridge: Cambridge University Press.

Shihab, M. Quraish, 1997, Membumikan al-Qur'an, Bandung: Mizan.

Syalaby, Ahmad, 1973, Sejarah Pendidikan Islam, diterjemahakan oleh Mukhtar Yahya dan Sanusi Latief, Jakarta: Bulan Bintang.

Makdisi, George, 1981, The Rise of College: Institutions of Learning in 
Islam and The West, Edinburgh: Edinburgh University Press.

Maksum, 1999, Madrasah: Sejarah dan Perkembangannya, Jakarta: Logos.

Ma'luf, Naji, 1973, Madaris Qabla alNizhamiyah, Bagdad: Majma' alIlmi al-Iraci.

Mursi, Muhammad Munir, 1977, AlTarbiyyah al-Islamiyyah: Ushuluha wa Tathawwuruha fi alBilad al-Arabiyyah, Kairo: 'Alam Kutub.

Nakosteen, Mehdi, 1994, Kontribusi Islam Atas Dunia Intelektual Barat: Deskripsi Analisis Abad Keemasan Islam, diterjemahkan oleh Joko S, Kahar dan Supriyanto, Surabaya: Risalah Gusti.

Nasr, Seyyed Hossein, 1968, Science and Sivilization in Islam, Cambridge, Massachusetts: Harvard University Press.

Neiberg, Michael S., 2002, Warfare in World History. Abingdon, United Kingdom: Routledge.

Pederson, J., 1996, Fajar Intelektualisme Islam : Buku dan Sejarah Penyebaran Informasi di Dunia Arab, diterjemahkan oleh Alwiyah Abdurrahman, Bandung: Mizan.

Qurtary, Muhammad al-, t.t. Al-Jami'ah al-Islamiyyah wa Dauruha fi
Masirat al-Fikr al-Tarbawy, Kairo, Daar al-Kutub al-'Araby.

Ramayulis, 1994, Ilmu Pendidikan Islam, Jakarta: Kalam Mulia.

Saad, Muhammad ibn, 2013, Tabaqat, vol. 3. Diterjemahkan oleh by Bewley, A. The Companions of Badr, London: Ta-Ha Publishers.

Stanton, Charles Michael, 1994, Pendidikan Tinggi dalam Islam, diterjemahkan oleh Affandi dan Hasan Asarij, Judul asli: Higher Learning in Islam: the Classical Period, A.D. 700-1.300, Jakarta: Logos.

Tibawi, A.L., 1972, Islamic Education: Its Traditions and Modernization into the Arab National System, London: Luzac and Company Ltd.

Tritton, A.S., 1957, Materials on Muslim education in the Middle Ages, London: Luzac and Company.

Watt, Montgomery, 1990, Kejayaan Islam: Kajian Kritis dari Tokoh Orientalis, diterjemahkan oleh Hartono Hadikusumo, Yogyakarta: Tiara Wacana.

Yatim, Badri, 1994, Sejarah Peradaban Islam, Jakarta: Rajawali Pers.

Yunus, Mahmud, 1990, Sejarah Pendidikan Islam, Jakarta: Hidakarya Agung. 